\title{
Religiusitas, Kecerdasaan Emosi, Dan Tawadhu Pada Mahasiswa Pascasarjana
}

\author{
Yola Tiaranita ${ }^{1 *}$, Salma Dias Saraswati ${ }^{2 *}$, Fuad Nashori $^{3}$ \\ ${ }^{1,2,3}$ Fakultas Psikologi Universitas Islam Indonesia, Yogyakarta, Indonesia
}

\begin{abstract}
College students are those people who educate themselves in university, that makes them have more knowledge than other students. But unfortunately, the more knowledge they have, the more they like to brag about themselves. Many people with higher education degree tend to brag about themselves to others in order to get appreciation, acknowledgement and respect. Those behaviors are against Islamic value that teaches us to be humble to others. This humility is called tawadhu' in Islam. The purpose of this research is to find out the effect of religiousity and emotional intelligence to tawadhu' in post-graduate students of UII. The subject of this research are 117 post-graduate students of UII. Based on double-regression in SPSS version 16, there is a correlation between religiousity and emotional intelligence to tawadhu' with signification value of $0,000(p<0,05)$ and $F$ score of 14,294.
\end{abstract}

Keyword(s): tawadhu, emotional intelligence, religiousity, post graduate students.

\begin{abstract}
ABSTRAK
Mahasiswa merupakan individu yang sedang menempuh pendidikan formal di perguruan tinggi, sehingga mereka memiliki tingkat ilmu pengetahuan yang lebih tinggi daripada pelajar lain. Namun tak jarang, banyaknya ilmu pengetahuan yang individu miliki, membuat individu menjadi sombong. Banyak individu dengan tingkat pendidikan yang tinggi pamer kepada orang lain dengan tujuan mendapatkan pengakuan, apresiasi dan penghargaan. Perilaku itu bertentangan dengan agama Islam yang mengajarkan individu untuk senantiasa bersikap rendah hati, seperti ilmu padi yang semakin berisi maka semakin merunduk. Sikap kerendahan hati dalam Islam disebut juga dengan tawadhu. Tujuan penelitian ini adalah meneliti pengaruh religiusitas dan kecerdasan emosi terhadap tawadhu' mahasiswa pascasarjana UII. Subjek penelitian ini berjumlah 117 mahasiswa pascasarjana UII. Berdasarkan uji regresi ganda, diketahui bahwa terdapat hubungan antara religiusitas dan kecerdasan emosi terhadap tawadhu' dengan signifikansi sebesar $0,000(p<0,05)$ dan F sebesar 14,294
\end{abstract}

Kata kunci: tawadhu, kecerdasan emosi, religiusitas, mahasiswa pascasarjan 


\section{PENDAHULUAN}

Manusia adalah makhluk sosial yang saling membutuhkan satu dengan lainnya. Sebagai makhluk sosial, manusia berkomunikasi, menjalin hubungan dan bekerjasama dengan orang lain, serta menerima dan memberi pertolongan, dan sebagainya. Dalam menjalin hubungan dengan orang lain diperlukan ilmu dan ketrampilan interpersonal.

Ilmu pengetahuan bisa didapatkan dari mana saja dan kapan saja, yang tentunya sangat bermanfaat dalam kehidupan sehari-hari termasuk dalam menjalin hubungan yang baik dengan orang lain. Selain itu juga, diasumsikan semakin berilmu seseorang maka orang tersebut akan semakin memiliki kerendahan hati. Seperti ilmu padi yaitu semakin berisi maka semakin merunduk.

Namun tak jarang, banyaknya ilmu pengetahuan dan yang individu miliki, membuat individu menjadi sombong. Banyak individu dengan tingkat pendidikan yang tinggi pamer kepada orang lain dengan tujuan mendapatkan pengakuan, apresiasi dan penghargaan. Banyak dari mereka yang juga pelit dalam membagi ilmu yang mereka miliki. Hal ini berdasarkan hasil observasi dan wawancara terhadap salah satu mahasiswa
Pascasarjana. Mereka juga seringkali merendahkan orang lain, misalnya dengan menganggap remeh mereka.

Perilaku itu bertentangan dengan agama Islam yang mengajarkan kita untuk senantiasa bersikap rendah hati atau tidak sombong, karena semua yang kita miliki, seperti bentuk rupa yang rupawan, harta, tahta atau kedudukan, bahkan ilmu pengetahuan dan ketrampilan merupakan karunia Allah SWT (Ilyas, 2001)

Sikap kerendahan hati dalam Islam disebut juga dengan tawadhu. Aghababaei, Blachnio, Arji, Chiniforoushan, Tekke, dan Mehrabadi (2015) mengatakan bahwa tawadhu' merupakan aspek ketulusan, keadilan, serta kesederhanaan yang memiliki kontribusi penting dalam membangun kerjasama dan hubungan interpersonal. Sikap tawadhu' cenderung mengundang rasa simpatik kepada sesama manusia. Orang yang memiliki sifat tawadhu' akan mengakui kesalahan dan merasa pengetahuannya masih kurang sehingga terbuka untuk menerima ide-ide baru dan nasihat yang bijaksana dari orang lain (Elliott, 2010). Sifat ini penting dimiliki setiap individu, terutama individu yang memiliki banyak ilmu pengetahuan, seperti mahasiswa pascasarjana. Mahasiswa pascasarjana diharapkan memiliki sikap tawadhu karena mereka 
Psikologia (Jurnal Psikologi), 2 (1), January 2017, 27-37

ISSN 2338-8595 (print), ISSN 2541-2299 (online)

Journal Homepage: http://ojs.umsida.ac.id/index.php/psikologia

DOI Link: 10.21070/psikologia.v2i1.568

nantinya akan menjadi pemimpin. Salah satu sifat yang harus dimiliki pemimpin adalah sikap tawadhu'.

Tawadhu' berarti merendahkan diri tanpa menghinakan dirinya sendiri atau meremehkan harga diri sehingga orang lain berani menghinanya dan menganggapnya rendahan (al-Hufy, 1978). Kerendahan hati (tawadhu') merupakan ekpresi dari penerimaan diri yang mendalam, tidak ada kebutuhan untuk membuktikan dirinya lebih dari orang lain (Elliott, 2010). Sedangkan menurut Amin (2013) yang dimaksud tawadhu adalah merendahkan diri dan berperilaku lembut, dimana perilakunya tidak bertujuan untuk dilihat sebagai orang yang terpuji namun semata-mata hanya mengharap ridha dari Allah swt.

Selanjutnya, menurut Mukmin (2006) agar seseorang tawadhu' maka harus memenuhi:

a. Mengenal dirinya sendiri

Hal ini dijelaskan dalam sebuah hadist yang berbunyi : "Barangsiapa mengenal dirinya pasti ia akan bertawadhu' kepada Allah" (HR. Imam Asy-Syafi' i)

b. Mengenal Allah, Sang Pencipta

Mengenal Allah mencakup 4 bagian, yaitu mengenal keberadaannya, keesaan rububiyah, keesaan uluhiyah (hak Allah untuk diibadahi) serta mengenal nama-nama dan sifat-sifat Allah.

c. Mengaplikasikannya dalam hal-hal berikut:

Pertama, tawadhu' dalam berpakaian. Kedua, tawadhu' kepada pembantu. Ketiga, tawadhu' dalam membangun rumah. Selanjutnya tawadhu' terhadap para kerabat, terutama yang miskin. Kelima adalah tawadhu' terhadap orang di bawah. Keenam, tawadhu' terhadap guru. Ketujuh, tawadhu' terhadap orang yang diajar. Kemudian yang terakhir adalah tawadhu' kepada orangtua.

Religiusitas adalah internalisasi nilainilai agama dalam diri seseorang. Internalisasi di sini berkaitan dengan kepercayaan terhadap ajaran-ajaran agama baik di dalam hati maupun dalam ucapan (Aviyah \& Farid, 2014). Kepercayaan ini kemudian diaktualisasikan dalam perbuatan dan tingkah laku sehari-hari. Ancok dan Suroso (2011) mendefinisikan religiusitas sebagai keberagamaan yang berarti meliputi berbagai macam sisi atau dimensi yang bukan hanya terjadi ketika seseorang melakukan perilaku ritual (beribadah), tapi juga ketika melakukan aktivitas lain yang didorong oleh kekuatan supranatural.

Glock dan Stark (dalam Ancok \& Suroso, 2011) melihat dimensi religiusitas 
Psikologia (Jurnal Psikologi), 2 (1), January 2017, 27-37

ISSN 2338-8595 (print), ISSN 2541-2299 (online)

Journal Homepage: http://ojs.umsida.ac.id/index.php/psikologia

meliputi dimensi keyakinan ideologis, dimensi praktik agama, dimensi pengalaman religius, dimensi pengetahuan agama, dan dimensi konsekuensi.

Kecerdasan emosi adalah kemampuan seseorang untuk memahami emosi yang dirasakannya, mampu mengendalikan diri dan emosi yang dirasakan, memiliki daya tahan dalam menghadapi masalah, mampu memotivasi diri, memahami perasaan dan emosi orang lain dan mampu membina hubungan yang baik dengan orang lain.

Goleman (2000) mengungkapkan lima aspek dalam kecerdasan emosi, yaitu :

1. Mengenali emosi diri

Mengenali emosi diri adalah kemampuan individu untuk menyadari emosi yang dirasakan oleh dirinya, memahami keseluruhan proses yang terjadi didalam dirinya, perasaan, dan pikirannya serta penyebab individu merasakan hal tersebut.

2. Mengelola emosi

Mengelola emosi adalah kemampuan individu untuk mengelola dan mengendalikan emosi-emosi yang dirasakan.

3. Memotivasi diri sendiri

Memotivasi diri sendiri adalah
kemampuan individu untuk
memotivasi diri ketika berada dalam
situasi yang membuat individu merasa

DOI Link: 10.21070/psikologia.v2i1.568 putus asa, mampu tetap berpikir positif, dan bersikap optiimis.

4. Mengenali emosi orang lain Mengenali emosi orang lain adalah kemampuan untuk memahami perasaan, emosi, pikiran dan tindakan orang lain berdasarkan sudut pandang orang tersebut.

5. Membina hubungan Membina hubungan atau keterampilan sosial adalah kemampuan membangun hubungan secara efektif dengan orang lain, mampu mempertahankan hubungan sosial tersebut, dan mampu menangani konflik-konflik interpersonal.

Berdasarkan uraian di atas, peneliti ingin meneliti pengaruh religiusitas dan kecerdasan emosi terhadap sikap tawadhu' mahasiswa pascasarjana UII.

\section{Hipotesis}

1. Ada hubungan antara religiusitas, kecerdasan emosi, dan tawadhu' pada mahasiswa pasca sarjana UII

2. Ada hubungan antara religiusitas terhadap tawadhu' pada mahasiswa pasca sarjana UII

3. Ada hubungan antara kecerdasan emosi terhadap tawadhu' pada mahasiswa pasca sarjana UII 
Tabel 1.

Populasi Penelitian (Jenis Kelamin)

\begin{tabular}{lc}
\hline Jenis Kelamin & Frekuensi \\
\hline Laki-laki & 68 \\
Perempuan & 49 \\
Jumlah & 117 \\
\hline
\end{tabular}

Tabel 2. Populasi Penelitian (Program Studi)

\begin{tabular}{lc}
\hline Pendidikan Pascasarjana & Frekuensi \\
\hline Sains & 45 \\
(T. Informatika, T. Sipil, Apoteker, Arsitektur, Manajemen Konstruksi) & \\
\hline Sosial (Hukum, Ekonomi, Psikologi Profesi) & 60 \\
\hline Sosial-islam (Hukum Islam, Ekonomi Islam, Pendidikan Islam) & 12 \\
\hline Jumlah & 117 \\
\hline
\end{tabular}

\section{METODE PENELITIAN}

Subjek dalam peneltian ini berjumlah 117 orang yang merupakan mahasiswa pascasarjana Universitas Islam Indonesia dengan rentang usia 20 sampai 52 tahun. Mahasiswa merupakan individu yang sedang menempuh pendidikan formal di perguruan tinggi.

Penelitian ini merupakan suatu penelitian korelasi yang melibatkan tiga variabel yaitu religiusitas dan kecemasan emosi sebagai variabel bebas, dan tawadhu' sebagai variabel tergantungnya. Data dikumpulkan menggunakan skala religiusitas dari Glock dan Stark (dalam Ancok \& Suroso, 2011) yang disusun oleh Sadewatama (2015) dengan reliabilitas sebesar 0.936 dan korelasi item bergerak antara 0.382-0.768. Skala kecerdasan emosi menggunakan skala dari Goleman (2000) yang disusun oleh Ulfah (2014) dengan reliabilitas sebesar 0.700 dan korelasi item bergerak antara 0.332-0.610, serta skala tawadhu' yang disusun sendiri oleh peneliti berdasarkan teori dan aspek dari Mukmin (2006) dengan religiusitas sebesar 0,681 .

Adapun analisis data menggunakan program SPSS versi 16 dengan analisis regresi ganda sehingga akan terlihat apakah religiusitas dan kecerdasan emosi mempengaruhi sikap tawadhu' seseorang.

\section{HASIL PENELITIAN}

Berdasarkan hasil analisis deskriptif, diperoleh bahwa nilai rata-rata pada religiusitas sebesar $81.39(\mathrm{SD}=6.61)$, rata-rata pada kecerdasan emosi sebesar $54.26(\mathrm{SD}=5.82)$ dan rata-rata pada tawadhu' sebesar $66.41(\mathrm{SD}=6.50)$.

Berdasarkan hasil analisis deskriptif, terlihat bahwa $16.2 \%$ individu memiliki sifat religiusitas yang tergolong sangat rendah, $19.7 \%$ individu tergolong rendah, 
Psikologia (Jurnal Psikologi), 2 (1), January 2017, 27-37

ISSN 2338-8595 (print), ISSN 2541-2299 (online)

Journal Homepage: http://ojs.umsida.ac.id/index.php/psikologia

DOI Link: 10.21070/psikologia.v2i1.568

$20.5 \%$ tergolong sedang, begitupula 23.1\% orang tergolong sangat tinggi.

dengan golongan tinggi, yaitu $20.5 \%$, serta

Tabel 3. Data Deskriptif

\begin{tabular}{lrrrc}
\hline & Min & Max & Mean & SD \\
\hline Religiusitas & 61 & 92 & 81.39 & 6.614 \\
Kecerdasan_Emosi & 41 & 72 & 54.26 & 5.821 \\
Tawadhu & 52 & 81 & 66.41 & 6.504 \\
\hline
\end{tabular}

Tabel 4. Kategorisasi Skala Religiusitas

\begin{tabular}{llll}
\hline Kategori & & Jumlah & Persentase \\
\hline Sangat Rendah & $\mathrm{x}<75.6$ & 19 & $16.2 \%$ \\
\hline Rendah & $75.6 \leq \mathrm{x}<80$ & 23 & $19.7 \%$ \\
\hline Sedang & $80 \leq \mathrm{x}<84$ & 24 & $20.5 \%$ \\
\hline Tinggi & $84 \leq \mathrm{x}<87$ & 24 & 20.5 \\
\hline Sangat Tinggi & $\mathrm{x} \geq 87$ & 27 & $23.1 \%$ \\
\hline
\end{tabular}

Tabel 5. Kategorisasi Skala Kecerdasan Emosi

\begin{tabular}{llll}
\hline Kategori & & Jumlah & Presentase \\
\hline Sangat Rendah & $\mathrm{x}<50$ & 21 & $17.9 \%$ \\
\hline Rendah & $50 \leq \mathrm{x}<53$ & 21 & $17.9 \%$ \\
\hline Sedang & $53 \leq \mathrm{x}<55$ & 18 & $15.4 \%$ \\
\hline Tinggi & $55 \leq \mathrm{x}<58$ & 25 & $21.3 \%$ \\
\hline Sangat tinggi & $\mathrm{x} \geq 58$ & 32 & $27.4 \%$ \\
\hline
\end{tabular}

Berdasarkan hasil analisis deskriptif, terlihat bahwa $17.9 \%$ individu memiliki kecerdasan emosi yang tergolong sangat rendah, begitupula dengan golongan rendah yaitu $17.9 \%, 15.4 \%$ tergolong sedang, $21.3 \%$ tergolong sedang, dan $27.4 \%$ tergolong sangat tinggi.

Berdasarkan hasil analisis deskriptif, terlihat bahwa $14.5 \%$ individu memiliki sifat tawadhu' yang tergolong sangat rendah, $19.7 \%$ tergolong rendah, $24.8 \%$ tergolong sedang, $19.7 \%$ tergolong tinggi dan $21.4 \% \mathrm{~T}$ tergolong sangat tinggi.
Sebelum melakukan uji hipotesis yaitu analisis regresi ganda, peneliti melakukan uji asumsi klasik yaitu uji normalitas, linearitas, multikolinieritas, dan heteroskedastisitas. Uji normalitas menggunakan uji formal dengan melihat normal probability plot menunjukkan bahwa letak titik plot berada tidak jauh dari garis linier sehingga nilai residual diasusmsikan terdistribusi normal dan asumsi kenormalan model terpenuhi. Analisa deskriptif dari plot tersebut juga menunjukkan tidak terjadi heteroskesdastisitas karena data tidak 
Psikologia (Jurnal Psikologi), 2 (1), January 2017, 27-37

ISSN 2338-8595 (print), ISSN 2541-2299 (online)

Journal Homepage: http://ojs.umsida.ac.id/index.php/psikologia DOI Link: 10.21070/psikologia.v2i1.568

menyebar acak. Selain itu, korelasi antara emosi juga menunjukkan hasil yang linier tawadhu' pada religiusitas dan kecerdasan (lihat tabel 3).

Tabel 6. Kategorisasi Skala Tawadhu'

\begin{tabular}{llll}
\hline Kategori & & Jumlah & Presentase \\
\hline Sangat Rendah & $\mathrm{x}<60.60$ & 17 & $14.5 \%$ \\
\hline Rendah & $60.60 \leq \mathrm{x}<65$ & 23 & $19.7 \%$ \\
\hline Sedang & $65 \leq \mathrm{x}<69$ & 29 & $24.8 \%$ \\
\hline Tinggi & $69 \leq \mathrm{x}<72$ & 23 & $19.7 \%$ \\
\hline Sangat tinggi & $\mathrm{x} \geq 72$ & 26 & $21.4 \%$ \\
\hline
\end{tabular}

Tabel 7. Hasil uji linearitas

\begin{tabular}{lll}
\hline & Sig & F \\
\hline Tawadhu*religiusitas & 0,00 & 20,405 \\
\hline Tawadhu*kecerdasan emosi & 0,00 & 22,505 \\
\hline
\end{tabular}

Normal P-P Plot of Regression Standardized Residual

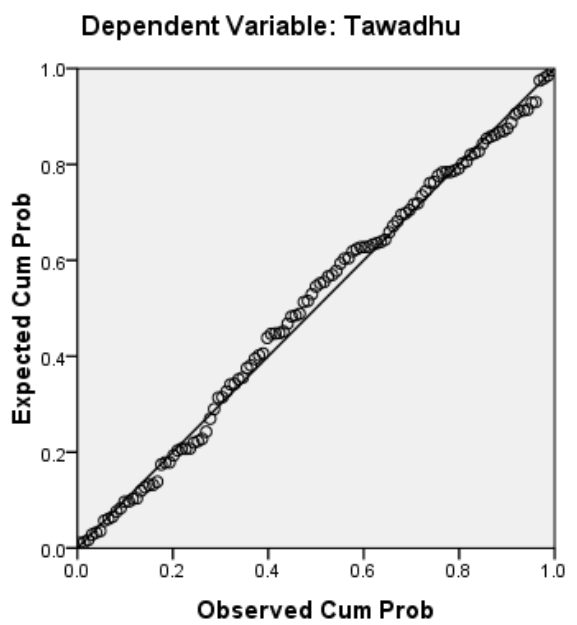

Selanjutnya untuk melihat ada atau tidaknya korelasi yang tinggi antara variabel bebas yang dapat mengganggu hubungan antara variabel bebas dan terikat, dilakukan uji multikolinearitas yaitu ditunjukkan dengan nilai VIF (Variance Inflation Factor) sebesar 1.406
(<10) sehingga disimpulkan bahwa tidak terjadi multikolinearitas (lihat tabel 5).

Berdasarkan hasil uji hipotesis menggunakan analisis regresi ganda pada tawadhu' (variabel tergantung), religiusitas dan kecerdasan emosi (variabel bebas) menunjukkan bahwa terdapat hubungan antara religiusitas dan kecerdasan emosi terhadap tawadhu', dengan signifikansi sebesar $0.000(\mathrm{p}<0.05)$ dan $\mathrm{F}=14.294$ (lihat tabel 8). Religiusitas dan kecerdasan emosi individu dapat memprediksi sifat tawadhu' yang dimiliki oleh individu. Peneliti melihat lebih lanjut bagaimana hubungan masing-masing variabel bebas tersebut terhadap variabel tergantung untuk membuktikan hipotesis minor peneliti. 
Tabel 8.

ANOVA $^{\text {b }}$

\begin{tabular}{|c|c|c|c|c|c|c|}
\hline \multicolumn{2}{|c|}{ Model } & \multirow{2}{*}{$\begin{array}{r}\text { Sum of Squares } \\
983.660\end{array}$} & \multirow{2}{*}{$\begin{array}{l}\mathrm{df} \\
\end{array}$} & \multirow{2}{*}{$\begin{array}{r}\text { Mean Square } \\
491.830\end{array}$} & \multirow{2}{*}{$\frac{F}{14.294}$} & \multirow{2}{*}{$\frac{\text { Sig. }}{.000^{\mathrm{a}}}$} \\
\hline 1 & Regression & & & & & \\
\hline & Residual & 3922.648 & 114 & 34.409 & & \\
\hline & Total & 4906.308 & 116 & & & \\
\hline
\end{tabular}

a. Predictors: (Constant), Kecerdasan_Emosi, Religiusitas

b. Dependent Variable: Tawadhu

Tabel 9

Coefficients $^{a}$

\begin{tabular}{|c|c|c|c|c|c|c|c|c|}
\hline \multirow{2}{*}{\multicolumn{2}{|c|}{ Model }} & \multicolumn{2}{|c|}{ Unstandardized Coefficients } & \multirow{2}{*}{$\begin{array}{c}\text { Standardized } \\
\text { Coefficients } \\
\text { Beta }\end{array}$} & \multirow{3}{*}{$\frac{t}{4.460}$} & \multirow{3}{*}{$\frac{\text { Sig. }}{.000}$} & \multicolumn{2}{|c|}{$\begin{array}{l}\text { Collinearity } \\
\text { Statistics }\end{array}$} \\
\hline & & \multirow{2}{*}{$\frac{B}{30.986}$} & \multirow{2}{*}{$\frac{\text { Std. Error }}{6.948}$} & & & & Tolerance & VIF \\
\hline 1 & (Constant) & & & & & & & \\
\hline & Religiusitas & .228 & .098 & .232 & 2.336 & .021 & .711 & 1.406 \\
\hline & $\begin{array}{l}\text { Kecerdasan_E } \\
\text { mosi }\end{array}$ & .311 & .111 & .278 & 2.800 & .006 & .711 & 1.406 \\
\hline
\end{tabular}

a. Dependent Variable: Tawadhu

Religiusitas memiliki korelasi dengan tawadhu' individu dengan nilai sig. sebesar $0.21(\mathrm{p}<0.05)$ dan $\mathrm{t}$ sebesar 2.336 (lihat tabel 9). Begitu pula dengan kecerdasan emosi yang memiliki korelasi terhadap tawadhu' yaitu dengan nilai sig. sebesar $0.006(\mathrm{p}<0.05)$ dan $\mathrm{t}$ sebesar 2.8 (lihat tabel 9). Hal tersebut menunjukkan bahwa baik religiusitas maupun kecerdasan emosi berpengaruh terhadap sikap tawadhu' individu.

Adapun hasil penelitian tersebut didukung oleh penelitian sebelumnya yang dilakukan oleh Aghababaei, dkk (2015) menyebutkan bahwa kerendahan hati memiliki korelasi yang kuat dengan tingkat religiusitas seseorang. Sehingga individu yang memiliki tingkat religiusitas yang tinggi, diprediksi memiliki tingkat tawadhu' yang tinggi pula.

Hubungan antara tawadhu' dan kecerdasan emosi seseorang dapat dilihat dari bagaimana individu dapat mengerti dan memahami perasaan orang lain. Seseorang yang mampu memahami perasaan orang lain tidak akan merendahkan orang lain. Tawadhu' itu sendiri adalah lawan kata dari kesombongan. Nabi Muhammad SAW mendefiniskan bahwa "kesombongan itu merupakan menolak kebenaran dan merendahkan martabat manusia." (HR. Muslim no. 261 dan At-Tarmidzi no. 1999). Padahal dengan kesombongan atau 
Psikologia (Jurnal Psikologi), 2 (1), January 2017, 27-37

ISSN 2338-8595 (print), ISSN 2541-2299 (online)

Journal Homepage: http://ojs.umsida.ac.id/index.php/psikologia

DOI Link: 10.21070/psikologia.v2i1.568

sifat takabur tersebut dapat menghambat seseorang untuk merasakan empati kepada orang lain. Menurut Hook, Watkins, Davis, Owen, Tongeren, dan Ramos (2016), sifat kerendahan hati seseorang dapat membangun rasa pengertian terhadap orang lain.

Individu yang memiliki kecerdasan emosi merupakan individu yang mampu memahami emosi yang dirasakan dirinya, mengerti penyebab individu merasakan hal tersebut serta mampu mengelola emosiemosi tersebut. Ini merupakan proses individu mengenal dirinya sendiri, hingga akhirnya individu memahami hakikat dirinya, kelebihan serta kekurangan diri individu tersebut. Pendalaman dalam mengenal diri sendiri ini pada akhirnya membuat individu memahami bahwa segala sesuatu yang dimilikinya merupakan karunia Allah SWT. Ilyas (2002) menyebutkan bahwa Individu yang menyadari dan memahami bahwa segala sesuatu yang mereka miliki, seperti bentuk rupa yang cantik atau tampan, harta, kekayaan, kedudukan, ilmu pengetahuan dan sebagainya berasal dari Allah SWT yang merupakan karunia dan anugrah-Nya kepada manusia, sehingga membuat individu tidak pantas bersikap sombong terhadap orang lain.

Religiusitas sendiri memiliki peran yang cukup besar dalam mempengaruhi sikap seseorang. Individu yang religius menyadari bahwa Allah SWT adalah Maha Besar atas segala seuatu, dan manusia adalah ciptaan Allah SWT yang banyak melakukan dosa-dosa, sehingga individu akan merasa bahwa dirinya ini hina atau tidak lebih baik daripada orang lain, sehingga individu akan lebih menghargai, dan menghormati oranglain, serta tidak meremehkan mereka.

Individu yang religius juga memahami bahwa mereka harus senantiasa mengamalkan ajaran Al-Quran dan Hadist, salah satunya itu berbuat baik dengan sesama dalam rangka mewujudkan habluminannas. Individu juga akan berusaha mencontoh perilaku Rasulullah terhadap sesama, misalnya bagaimana Rasulullah menanggapi orang lain yang mengejek, bagaimana Rasulullah berbicara dengan orang lain, memperlakukan orang yang lebih tua, tetangga, dan sebagainya. Usaha untuk meneladani Rasulullah ini akan tercermin dalam perilaku tawadhu' individu, antara lain berbicara dengan nada rendah, tidak menghardik orang lain, memuliakan tamu dan lain-lain.

Jenis pendidikan yang ditempuh individu tidak memiliki pengaruh terhadap tingkat tawadhu' yang dimiliki individu. Berdasarkan uji beda terhadap ketiga kelompok jurusan pendidikan, menghasilkan sig. sebesar 0,469 ( $>>0,05)$ 
Psikologia (Jurnal Psikologi), 2 (1), January 2017, 27-37

ISSN 2338-8595 (print), ISSN 2541-2299 (online)

Journal Homepage: http://ojs.umsida.ac.id/index.php/psikologia

DOI Link: 10.21070/psikologia.v2i1.568

dan $\mathrm{F}$ sebesar 0,762 sehingga tidak ada perbedaaan tawadhu yang dimiliki antar kelompok pendidikan.

Asumsi peneliti bahwa terdapat perbedaan antara kelompok pendidikan sains, sosial, dan sosial-islam ditolak. Hal tersebut dimungkinkan mengingat bahwa subjek penelitian merupakan mahasiswa pasca sarjana di salah satu Universitas swasta di Yogyakarta yang berlandaskan nilai keislaman. Setiap lmu yang bermanfaat dianjurkan oleh Islam untuk dipelajari dan diamalkan.

\section{SIMPULAN}

Berdasarkan hasil penelitian, dapat disimpulkan bahwa terdapat korelasi yang signifikan antara tawadhu' pada mahasiswa pasca sarjana UII ditinjau dari religiusitas dan kecerdasan emosi. Artinya, religiusitas dan kecerdasan emosi memiliki pengaruh terhadap tawadhu'. Dari hasil penelitian jug adapat disimpulkan bahwa terdapat hubungan positif yang signifikan antara religiusitas terhadap tawadhu'. Artinya, semakin tinggi religiusitas yang dimiliki mahasiswa, maka semakin tinggi pula sikap tawadhu' yang dimilikinya. Hal ini berlaku sebaliknya, semakin rendah religiusitas mahasiswa, maka semakin rendah pula sifat tawadhu' yang dimilikinya.
Selain itu, terdapat pula hubungan yang positif antara kecerdasan emosi terhadap tawadhu'. Artinya, semakin tinggi kecerdasan emosi yang dimiliki mahasiswa, maka semakin tinggi pula sikap tawadhu' yang dimilikinya. Hal ini berlaku sebaliknya, semakin rendah kecerdasan mahasiswa, maka semakin rendah pula sifat tawadhu' yang dimilikinya.

\section{DAFTAR PUSTAKA}

Aghababaei, N., Blachnio, A., Arji, A., Chiniforoushan, M., Tekke, M., \& Mehrabadi, A.F. (2015). Honestyhumility and the hexaco structure of religiosity and well being. Curr Psychol, 35(3), 421-426

Al Hufy, A.M. (1978). Akhlak Nabi Muhammad saw: Keluhuran dan Kemuliaan. Jakarta: Bulan Bintang

Amin, S. (2013). Sifat Tawadhu' Rasulullah shalallahu'alaihi wasallam (terjemahan oleh Abu Umamah Arif Hidayatullah). Diakses dari IslamHouse.com

Ancok, D. \& Suroso, F.N. (2011). Psikologi Islami Solusi Islam atas Problem-problem Psikologi. Yogyakarta: Pustaka Pelajar.

Aviyah, E. \& Farid, M. (2014). Religiustas, kontrol diri dan kenakalan remaja. Persona, 2(02), 126-129

Elliott, J.C. (2010). Humility: Development and analysis of scale. Disertasi. University of Tennessee. 
Psikologia (Jurnal Psikologi), 2 (1), January 2017, 27-37

ISSN 2338-8595 (print), ISSN 2541-2299 (online)

Journal Homepage: http://ojs.umsida.ac.id/index.php/psikologia

Goleman, D., (2000), Emotional Intelligence, Jakarta : PT. Gramedia Pustaka Umum

Hook, J.N., Watkins, C.E., Davis, D.E., Owen, J., Van Tongeren, D.R., \& Ramos, M.J. (2016). Cultural humility in psychotherapy supervision. American Journal of Psychotherapy, 70(2), 149-166.
DOI Link: 10.21070/psikologia.v2i1.568

Ilyas, Y. (2001). Kuliah Akhlaq. Yogyakarta: Pustaka Pelajar

Mukmin, A. (2006). Semulia Akhlak

Nabi. Surakarta: Aqwam 